\title{
Arranging events for entrepreneurs: waste of money or value for money
}

Michael C. Cant

University of South Africa (Unisa), South Africa

Department of Marketing and Retail Management

\section{Key words}

Small business, entrepreneurs, events, entrepreneurship day, starting a small business, applying for finance

\begin{abstract}
The development of the entrepreneurs of a country is regarded as central to the creation of jobs and the upliftment of communities. All countries have associations and institutions that focus on the development of small business and the assisting of entrepreneurs to grow and develop their businesses. In the USA, EU, Asia and South America, governments are investing huge amounts of money in the development of an entrepreneurial spirit, and to especially stimulate young entrepreneurs to start their own businesses. Many offer the standard services of seminars, workshops, special events, brochures, and mentoring but little research has been done to establish whether these interventions are useful and helpful to entrepreneurs. Research generally focuses on the training needs of entrepreneurs, the profile of entrepreneurs, SMME needs and so forth. It is seldom that specific events are evaluated to determine whether they meet the needs of entrepreneurs and if the entrepreneurs found some benefit from it or not.

The aim of this research study was to establish if entrepreneurs felt they received some benefit from these interventions or not. It was found that entrepreneurs do find these events beneficial and that their needs and expectations are met. More than $71 \%$ of entrepreneurs were of the opinion that such events do meet their needs. It is however suggested that these types of events be more specific on what they will present, such as how to apply for finance, the processes involved in starting a business and conducting market research.
\end{abstract}

Corresponding author: Michael C. Cant

Email address for corresponding author: cantmc@unisa.ac.za

First submission received: 13th February 2017

Revised submission received: 18th March 2017

Accepted: 14th April 2017

\section{Introduction}

Small, Medium and Micro Enterprises (SMMEs) play a central role in any country's economy. As larger businesses are battling more and more to maintain their momentum and, in many cases, downsizing due to the prolonged economic downturn, the focus is more and more on SMMEs to drive economic growth, innovation and job creation. Many developing countries, and in some instances developed countries, have dedicated ministers or departments focused on small business development. South Africa is no different, and in 2014 a new Ministry of Small Business Development, with its main focus on the development and promotion of small businesses, was instituted.

The importance and value of the SME/SMME sector is recognised around the world irrespective of a countries developmental status, however, in developing countries SMEs/SMMEs tend to play a larger role and responsibility in employment and economic growth (Marnewick, 2014). 
SMEs/SMMEs further have the potential to develop entrepreneurial skills and enhance market opportunities (IOL, 2014).

A study conducted by the World Bank identified the following key benefits of SMMEs to the economy (Morongwa Makakane, 2014; WebFinancial, 2011):

1 SMMEs are the engine of growth: SMMEs play a pivotal role in job creation in the country.

2 SMMEs are essential for a competitive and efficient market: The approach to competition used by SMMEs drives efficiency and productivity.

$3 S M M E s$ are critical for poverty reduction: SMMEs due to being located mostly outside big towns and commercial areas allows these businesses to employ local individuals, whereby alleviating poverty and promoting economic activity.

4 SMMEs play a particularly important role in developing countries: SMMEs drive diversification by developing new and unsaturated sector in the economy.

SMEs/SMMEs are usually defined by three criteria namely: assets, number of employees, and revenue generated per annum. These figures, however, tend to vary by country and can even be different according to industry (Marnewick, 2014). Hence, there is no formal worldwide definition for that of an SME (Katua, 2014:462). According to the Organisation for Economic Co-Operation and Development (OECD, 2005 in BER Report, 2016) Small and Medium sized Enterprises (SMEs) are independent, non-subsidiary firms that employ less than a certain number of employees. The number of employees can be seen to differ by country, for example in the United States SMEs can be seen to have less than 500 employees and in the European Union less than 250 employees (OECD, 2005, in BER Report, 2016), the most frequent upper limit is that of 250 employees, small firms often containing less than 50 employees and micro-enterprises not more than ten and in some instances less than five (OECD 2005 in BER Report, 2016).

\subsection{Events for entrepreneurs in perspective}

In the constantly changing and evolving business sphere, traditional methods of marketing is replaced by more unique and innovative and exciting approaches - but when it comes to good old-fashioned face-to-face marketing, business events can be an invaluable platform (Business events: Essential tips for SMEs, n.d)

An SMME event is aimed at encouraging and getting those thinkers and doers in the industry to get involved in business and make contributions towards employment and upliftment. As an attendee of these events it is seen as the ideal forum to advance an entrepreneurs business.

Business events offer numerous benefits to SMMEs. In all stages of the event, events offer businesses a chance to be proactive and manage their business plans, their marketing plans and the overall management of their business (Business events: Essential tips for SMEs, n.d).

Events in general offer opportunities to explore options, to build networks, to expand on existing relationships, to obtain insights and information, and it can be a catalyst to gather business leads and turn them into clients. Events furthermore offer an opportunity to establish networks in other sectors in the business sphere and also extending contacts and networks there.

Events focussed on assisting entrepreneurs can take on numerous forms and many are focussed on assisting entrepreneurs to get started or to grow their business. It is therefore important that entrepreneurs understand their own goals for attending such an event. By having a clear reason entrepreneurs will be in a better position to ascertain whether the event has met their expectations or not. By knowing what they expect to achieve at such an event it will be possible to give an opinion of the effectiveness of such an event.

The presents of events also need to have their own set of goals they aim to achieve, and should in all cases evaluate the achievement of their goals after each event. This makes it possible to further improve on future events and the addressing of the expectations of participants. 


\section{SMEs/SMMEs Defined}

The National Small Business Act (Act No. 102 of 1996) defines a small business organisation as follows:

"... any entity, whether or not incorporated or registered under any law, which consists mainly of persons carrying on small business concerns in any economic sector, or which has been established for the purpose of promoting the interests of or representing small business concerns, and includes any federation consisting wholly or partly of such association, and also any branch of such organisation" (The Department of Trade and Industry, n.d.).

The National Small business Act (Act No.102 of 1996) in defining the various categories of SMMEs can be seen to use the size of the business and annual turnover as a measure (Marnewick, 2014). Table 1 is indicative to the various categories of SMMEs.

\begin{tabular}{|c|c|}
\hline Category & Description \\
\hline $\begin{array}{l}\text { Survivalist } \\
\text { enterprise }\end{array}$ & $\begin{array}{l}\text { A survivalist enterprise can be seen to form part of the micro-enterprise sector and } \\
\text { operates in the informal sector. Such businesses are usually started by } \\
\text { unemployed individuals, the enterprise will have few capital assets, owners are } \\
\text { not well trained and the income that these enterprises generate can be seen to be } \\
\text { less than the minimum income generated by businesses (income is below the } \\
\text { poverty line). The opportunity for growth in these enterprises is small. Examples } \\
\text { of survivalist enterprises include: Vendors, hawkers and subsistence farmers. }\end{array}$ \\
\hline $\begin{array}{l}\text { Micro- } \\
\text { enterprise }\end{array}$ & $\begin{array}{l}\text { Micro-enterprises are enterprises that do not register their business formally (no } \\
\text { license) as their turnover is less than the amount stipulated by the South African } \\
\text { value-added tax registration limit (R300 000). These businesses do not employ } \\
\text { more than five people, usually family members. Owners usually have the basic } \\
\text { training and business skills and have the potential to transform their business to } \\
\text { the formal sector. Examples of micro-enterprises include minibus taxis, household } \\
\text { industries and spaza shops, which refers to a "hidden" or "camouflaged shop } \\
\text { within a township. }\end{array}$ \\
\hline $\begin{array}{l}\text { Very small } \\
\text { enterprise }\end{array}$ & $\begin{array}{l}\text { A very small enterprise can be seen to operate in the formal sector and do not hire } \\
\text { more than ten employees, unless in construction, mining, electricity or } \\
\text { manufacturing sector, in which they do not employ more than } 20 \text { employees; } \\
\text { these enterprises have access to ICT/ technology. Example: Plumbers and } \\
\text { electricians. }\end{array}$ \\
\hline $\begin{array}{l}\text { Small } \\
\text { enterprise }\end{array}$ & $\begin{array}{l}\text { A small enterprise can be seen to operate in the formal sector and employ not } \\
\text { more than } 50 \text { employees. Such businesses can be seen to operate with a more } \\
\text { complex business structure. }\end{array}$ \\
\hline $\begin{array}{l}\text { Medium } \\
\text { enterprise }\end{array}$ & $\begin{array}{l}\text { A medium enterprise can be seen to include additional management structures } \\
\text { within their business, they employ a maximum of } 100 \text { employees, however if they } \\
\text { fall within the construction, mining, electricity or manufacturing sector the } \\
\text { enterprise could employee up to } 200 \text { employees. }\end{array}$ \\
\hline
\end{tabular}

Table 1: Categories of SMMEs in South Africa

Source: Adapted from: Marnewick (2014) and Entrepreneur's toolkit (2009)

Apart from the above description of SMEs/SMMEs small businesses according to the Entrepreneur's toolkit (2009) can further be divided between established formal SMEs/SMMEs in mainly urban areas and emerging SMEs/SMMEs situated in informal settlements, rural areas and townships. The largest group of SMEs/SMMEs falls in the survivalist category meaning, that majority of SMEs/SMMEs are operating in the informal sector and are not receiving support (Entrepreneur's toolkit, 2009). For the purpose of this research study, emerging SMEs/SMMEs will be the focus. 


\section{SMEs/SMMEs in South Africa}

Research indicates that there are an estimated 5.9 million SMEs/SMMEs in South Africa (University of Johannesburg, 2015), that contribute roughly 52-57\% of the South African GDP, and contribute $60 \%$ towards national employment, which in essence means that the SME sector provides more employment than that of the private and government sector together and roughly $40 \%$ to the total South African remuneration (Morongwa \&Makakane, 2014; Bank Seta, n.d.; Habberton\& Notcutt, 2013, Ntingi, 2014; South African Small Medium Enterprise Federation, 2015). With an unemployment rate of over 25\% (Staff writer, 2013; SA news, 2014), SMEs play a pivotal role in developing the economy. The problem, however, is that according to the rest of the world and even the rest of the African continent, South Africa can be seen to have the lowest entrepreneurial activity, which means that the country has yet to see the full value and benefits of SMEs/SMMEs (IOL, 2014).

\section{Challenges faced by SMMEs}

SMMEs face a number of challenges and it is a known fact that most small businesses worldwide face the same challenges- although to a lesser or higher extend depending on the country. Some of the more prominent challenges faced my SMMEs are indicated and discussed below.

\subsection{Access to finance and credit}

SMMEs lack the capital to run their business effectively and it is a challenge to secure the funding they require. According to the Department of Small Business Development (2015) a total of $79 \%$ of informal SMEs do not have a bank account; $96.8 \%$ had loans from friends or family for daily operations. More than $95 \%$ have no credit facility, or asset finance or a mortgage loan for their business.

Entrepreneurs starting their own businesses are generally discouraged due to the fact that they do not have easy access to finance or credit. As stated by the Financial Services Regulatory Task Group, (in BER Report, 2016) this situation is not uncommon. Very few financial institutions are willing today to invest in a start-up business due to their averseness to risk in this sector, the laws and regulations instituted by governments to protect lenders against risky loans, and the general mistrust in the success of small businesses. They are therefore more inclined to only invest or provide loans to SMMEs who have some sort of record- that means being operational and showing potential to survive. The main reasons for SMMEs and entrepreneurs not securing finance lies in the fact that they do not have a credit track record, no proven business experience in the field they want to start a business, no collateral or security for the loan, no business or marketing plan based on the requirement of the institution, as well as limited or no market research, the absence of a viable business idea, and no access to markets (GEM, 2014 in BER Report 2016).

\subsection{Inadequate infrastructure}

The availability of proper physical infrastructure is a key element for success for SMMEs. This however comes at a price, which many SMMEs and entrepreneurs cannot afford. To secure a prime location or have sufficient space for the manufacturing of products can be expensive and may require a long term lease- something that requires finances as well. The 2014 GEM South Africa report (in BER Report, 2016) made it clear that proper infrastructure is a key enabler for SMME development. The infrastructure, however, is not limited to buildings for retail or office purposes, but includes sanitation, electricity, water and telecommunications/ WiFi at an affordable cost to small businesses.

\subsection{Strategic alliances}

The fact that small businesses tend to battle to enter and penetrate the markets they aim to satisfy due to various reasons, including capacity and consistent quality standards, implies a need for cooperative agreements with larger and established businesses. These alliances can be instrumental in assisting small businesses in all countries to establish a footprint in the market, to overcome new business pitfalls and to eventually stand on its own feet on a solid and sound business 
platform. These alliances should be forged with established businesses in the sector of operation and can start off as being a sub-contractor. These alliances are however scarce due to a slow economy, mistrust and unknown performance statistics from these entrepreneurs and SMMEs. In South Africa specifically this is a major problem with nepotism and corruption keeping many businesses out of larger contracts.

\subsection{Legal processes}

Many SMMES find it difficult to conform to the legal requirements of government regarding the starting of their businesses.

While there are many laws within the Republic of South Africa's governing enterprises, Lionel Billings, the Head of Consulting Services of Business Partners Limited, indicates that the more pertinent Acts which businesses should be familiar with are (Business Partners Limited, 2013):

- Companies Act

- $\quad$ Consumer Protection Act

- $\quad$ National Credit Act

- $\quad$ Protection of Private Information Act

- $\quad$ Promotion of Access to Information Act

- $\quad$ Broad-based BEE Bill

- $\quad$ Employment Equity Act

An article written by Webster and Harris (2016) further provide multiple links to legislation that is important for SMMEs to be aware of, these include:

\section{Labour legislation}

Webster and Harris (2016) indicate one of the more important laws to be aware of is the Basic Conditions of Employment Act, this act regulates the following:

- Working times

- $\quad$ Payment Leave

- $\quad$ Deductions

- $\quad$ Notice periods

- $\quad$ Administration

- $\quad$ Prohibition of victimisation

Tax Laws

- The SME Toolkit (http://southafrica.smetoolkit.org/sa/en/ category /2942/Tax-SARS)

- $\quad$ SARS' small business page (http://www.sars.gov.za/home.asp?pid=169)

Health and safety

- Department of Labour basic guides to ten aspects of health and safety (http://www.labour.gov.za/legislation/acts/basic-guides/basicguides-Health\%20and\%20Safety/)

- $\quad$ Labour Guide Health \& Safety page (http://www.labourguide.co.za/health-and-safety/)

Consumer protection

- $\quad$ Bank Seta CPA training Manual (http://www.bankseta.org.za/downloads/ BANKSETA_CPA_Training_Manual.pdf)

- Webber Wentzel legal brief on the CPA (http://www.polity.org.za/article/introduction-ofnew-laws-to-protectconsumers-imminent-2011-03-11)

It is clear from the above that it is a daunting task for SMMES to meet these requirements and which can discourage many entrepreneurs from starting a business. 


\subsection{High levels of crime}

The high level of crime experienced in South Africa is a serious problem that all businesses have to deal with - and SMMEs maybe more than others. A survey conducted in 2015 by the OECD (in BER Report, 2016)noted that SMMEs are forced to spend additional funds on security due to the high levels of crime - money they can ill afford to spend on this non income generating operational need. .

\subsection{Access to markets}

SMMEs find it difficult to access markets as they have no proven record, established supply record and so forth, which in effect prompt financial institutions to deny them finance. This is a classic catch 22 situation that SMMEs find themselves in. This situation is even worse for SMMEs in townships or rural areas, as the relatively small size of these SMMEs and their location away from the mainstream of industrial areas makes it more difficult for them to compete (Watson \& Netswera, 2009). This fact makes it more difficult for them to establish themselves as a viable business.

In summary, SMMEs in South Africa face a number of challenges and the following highlights some of these challenges not yet referred to above(Bank Seta, n.d.; The Banking Association South Africa, 2016; Agwa-Ejon \& Mbohwa, 2015; Small Business Academy Research Division, 2014.):

- There is a weak entrepreneurial culture/drive within South Africa.

- There is crime and corruption.

- Many SME owners lack management skills and experience and their staff lack the relevant skills.

- There is a high barrier to entry/ difficult to find a market for their products and develop relationships with customers.

- SMEs lack appropriate technology and therefore have low production capacity, this includes access to electricity.

- Insufficient support provided in terms of their contribution to the economy.

- High level of competition/ dominance of business groups.

Despite the many challenges that SMEs face, some of these encounters can be overcome if approached correctly and methodically. In order to assist small businesses various initiatives are implemented by governments and other institutions with the aim of helping small businesses to overcome the challenges they face and to allow them to enter the mainstream economy. These initiatives, such as entrepreneurs' day, are focused on covering all relevant aspects of starting a business and to enlighten and educate entrepreneurs as to the processes and road ahead. It is seen as a method to educate and help entrepreneurs to start their businesses on a sound footing and enhance their chances of success.

\section{Research Methodology}

The primary objectives of the research project were to obtain feedback from the attendees of an event regarding the usefulness and value of the event. The primary objectives were as follows:

- To identify and validate the key benefits of hosting an events day like the Entrepreneur's Day;

- The effectiveness of such an event to attract entrepreneurs to the institution's service offering or site;

- To establish the effectiveness and relevance of information provided to people in starting their own business.

In order to meet the objectives of the project and to secure valuable input for future events a structured approach was followed in the research process

A questionnaire was developed for the interviews with attendees. The questionnaire was structured and used various techniques to gather information. The research covered a significant cross section of attendees. The questionnaire was detailed and included both a qualitative and quantitative 
component. The questionnaire was done online and completed by the interviewer while talking to the attendee. There were a number of open-ended questions for qualitative feedback by clients.

The fieldworkers underwent proper and effective training to ensure that the quality of responses is both valid and of a high quality. The data was captured for input to the statistical software. Quality control checks were conducted on the quality of the input.

Initially the sample size was to be based on the percentage splits per province in South Africa. However, due to the illegibility of some of the registers provided as well as the small number of names on some of the provinces' registers this was not possible and more emphasis was placed on achieving the 700 responses within the time frame allocated. A total of 702 completed surveys were used in the analysis.

It is believed that the results of the survey are statistically significant and that the information gained from the survey would be useful in applying as regards input for future events.

\section{Research Findings}

The questions as posed to the attendees are indicated below.

\subsection{Geographic region}

The focus of the study was to make sure all provinces in South Africa were included in the research. Figure 1 below shows the geographic regions and the percentage of respondents that attended the Entrepreneurs 'Day in each of these regions.

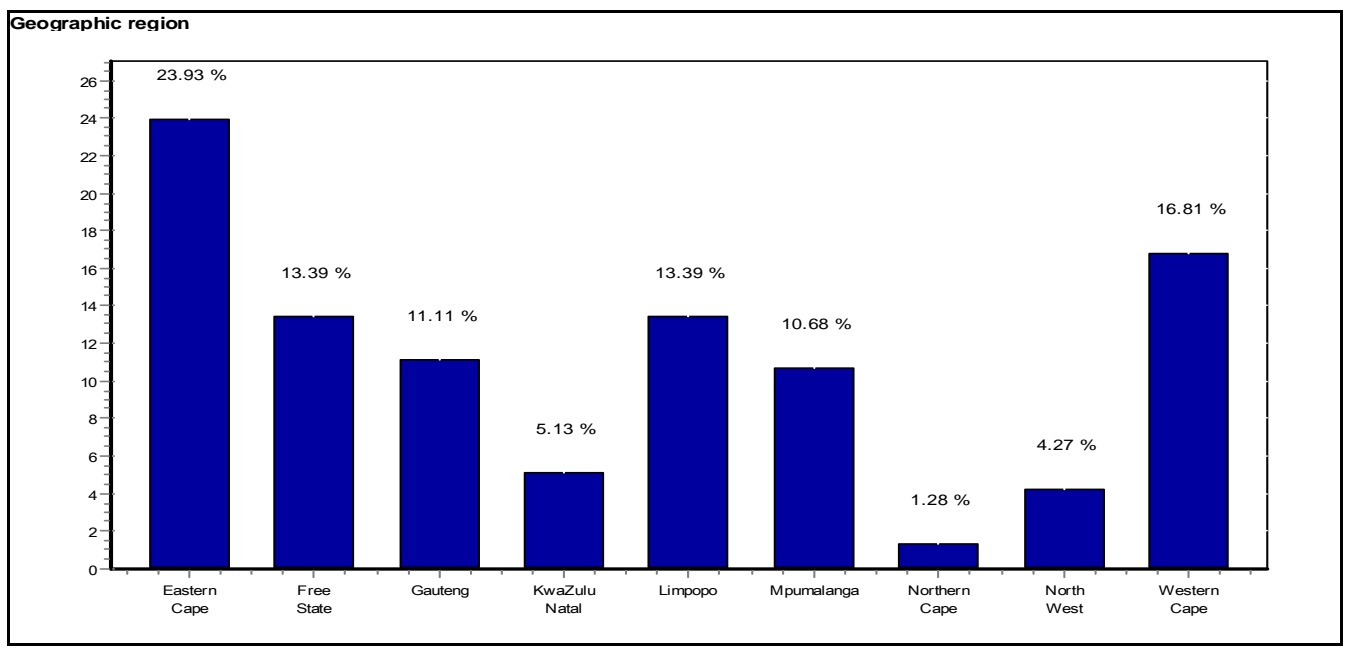

Figure 1: Geographic region

Results indicate that the largest proportion of respondents is from the Eastern Cape, followed by the Western Cape. The smallest number of respondents was from the North Cape. It was interesting that a relatively small percentage of respondents were from Gauteng, which is the economic hub of South Africa.

\subsection{Frequency of event attended}

This question asked respondents to indicate whether the event was their first, second or third event attended. The results are shown in figure 2. 


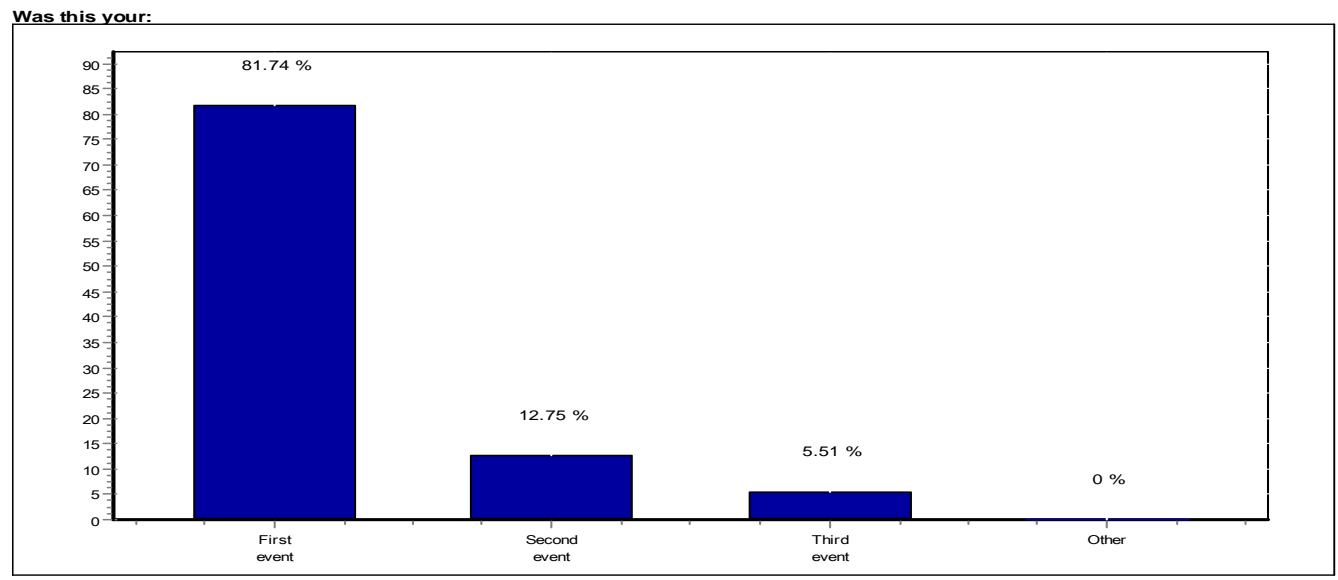

Figure 2: Number of events attended

For $82 \%$ of the respondents, the event researched was the first event attended while for $13 \%$ of respondents it was the second event attended. It would seem from these responses that entrepreneurs do not make it a habit of attending a number of events as they expect to find the answers they are looking for from one visit.

\subsection{Reason for attending the event}

This question asked the respondents to indicate their main reasons for attending the event. Figure 3 below shows these reasons.

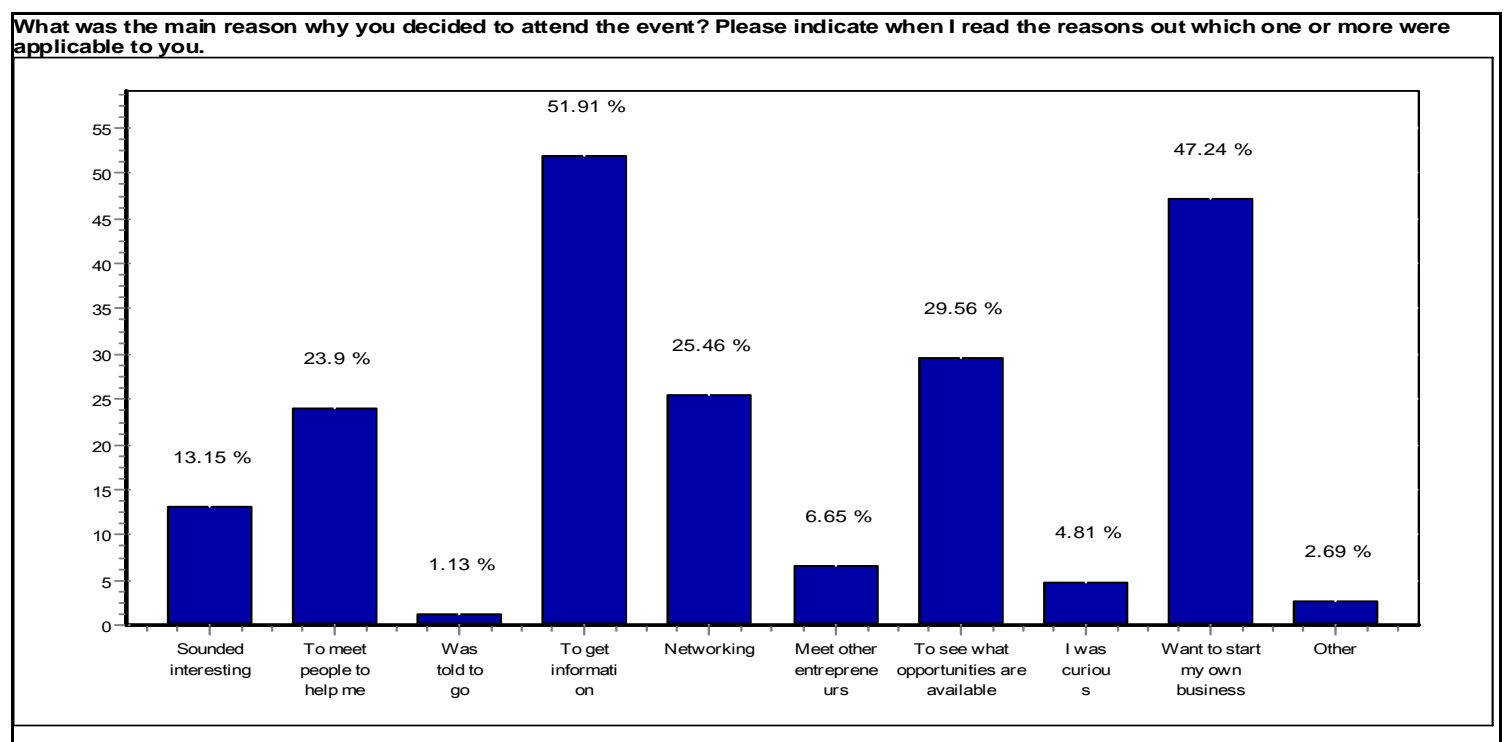

Figure 3: Reason for attending event

The most popular reason for attending the event was "To get information" (52\%), followed by "Want to start my own business" (47\%). This would imply that the main reason/aim for offering the event is being met. What is also important is that a substantial number of respondents were looking for opportunities to start a business (30\%); networking (25\%) and to find help (24\%). These reasons can all be utilised in future presentations to enhance the experience of the attendees, as well as to market these events.

\subsection{Extent to which event met needs of attendees}

Attendees were asked to rate, on a scale of 1 to 5 , with 1 being "Not at all" and 5 being "Perfectly", whether the event had met their needs. The results are presented in figure 4 below. 


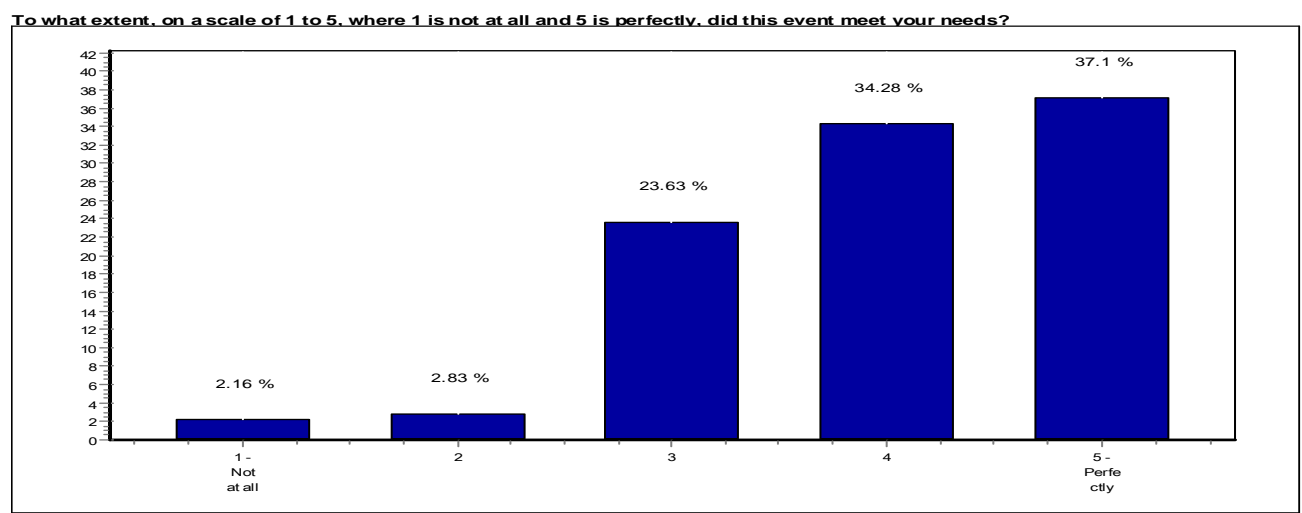

Figure 4: Extent to which event met needs

The majority $(71 \%)$ of respondents gave a rating of 4 or above indicating that the event met the needs of most of the attendees. In a global sense this means that the event adds value to the attendees' needs and expectations.

\subsection{Information respondents expected to find at event}

This question asked the respondents to indicate what specific information they expected to find at the event. Figure 5 shows the responses to this question.

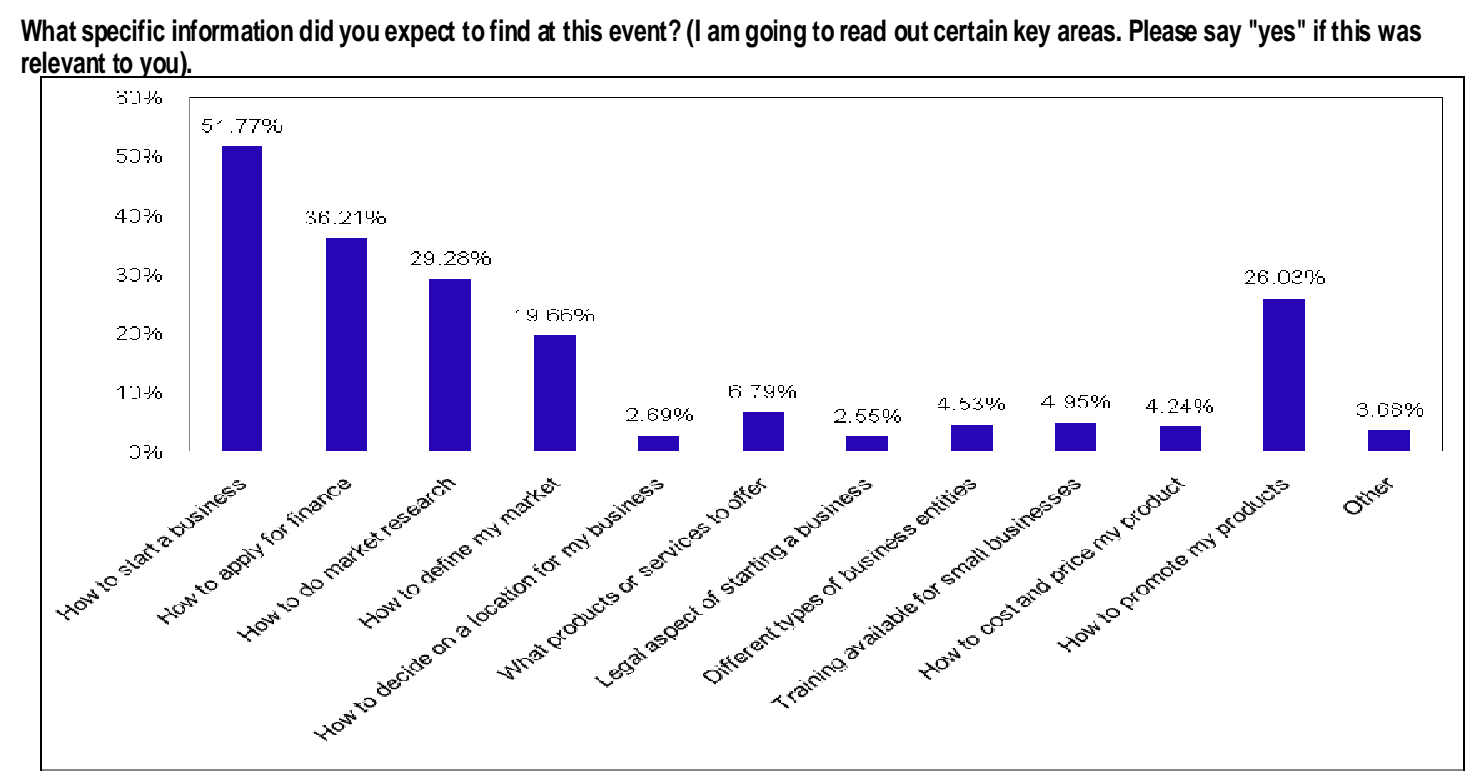

Figure 5: Information expected to find at event

The specific information that respondents expected to find at the event was to find information $(52 \%)$ on how to start a business, while $36 \%$ expected to find information on how to apply for finance. These responses are in line with the findings in the literary review where the challenges of entrepreneurs were highlighted. What attendees also expected was to establish how to do research (29\%) and how to promote/market their products/business (26\%). From all these responses it is clear that the topics respondents want more information on or why they attended is to:

- Find out the steps to start a business;

- How to get finance;

- How to do research; and

- How to market their business or product.

The focus for these types of events would seem to have to be on these issues in future. 


\subsection{Did the information provided meet your expectations}

On a scale of 1 to 5 , with 1 being "Not at all" and 5 being "Perfectly", respondents were asked to rate how the information obtained from the event met their expectations. The results are shown in figure 6 below.

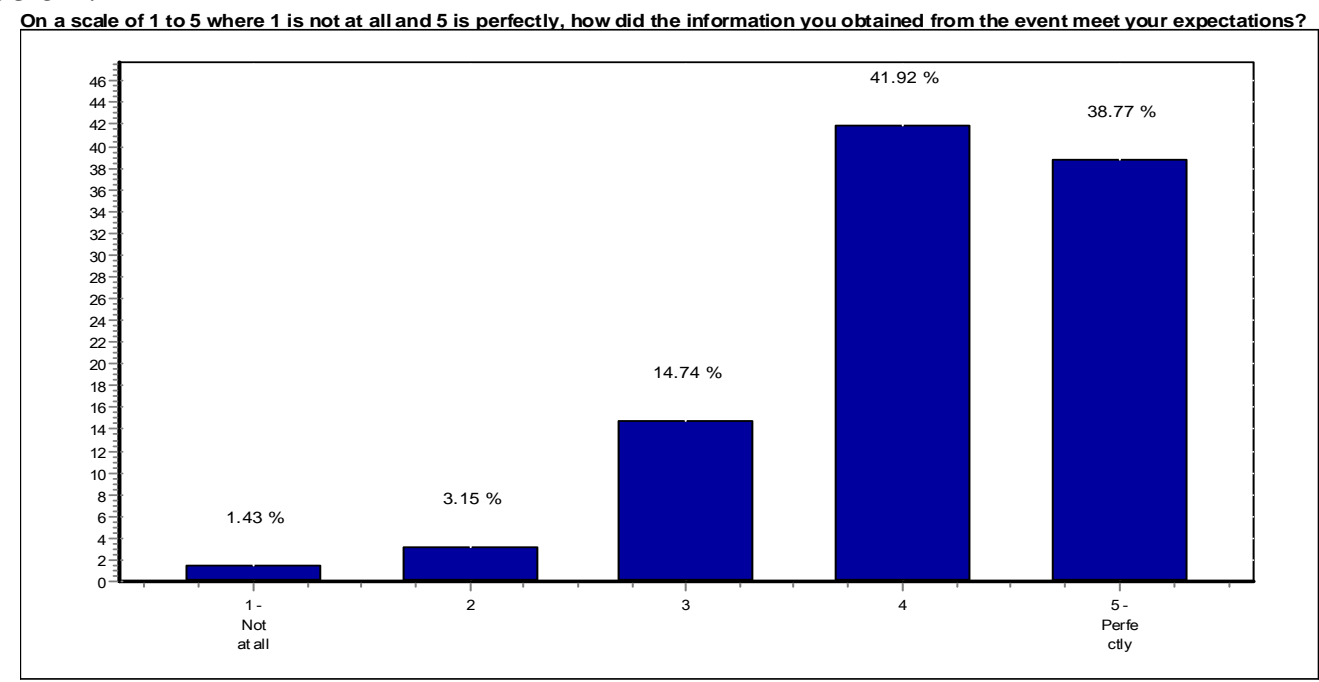

Figure 6: Did the information obtained meet expectations as indicated in previous question

The majority $(81 \%)$ of respondents gave a rating of 4 or above indicating that the information obtained at the event did meet their expectations. Only $1 \%$ gave a rating of 1 meaning that the event did not meet their expectations at all. This would seem to emphasise the fact that the information provided are useful to the respondents. It would also seem that expectations of attendees are met.

\subsection{Was it worth the effort to attend the event to obtain the information}

Respondents were asked to rate whether it was worth the effort to attend the event to obtain the information. The scaling was from 1 to 5 with 1 being not at all and 5 definitely. The results are shown in figure 7 below.

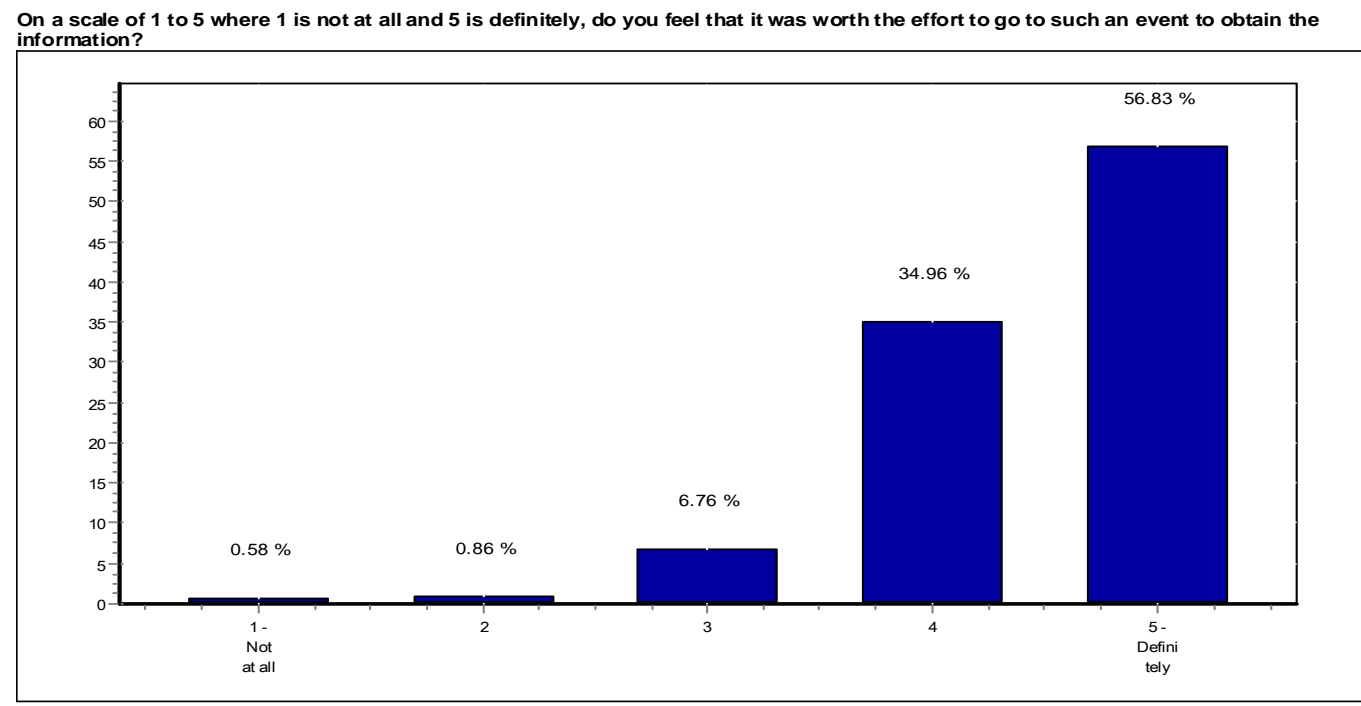

Figure 7: Worth effort to attend

$57 \%$ of respondents definitely felt that it was worth the effort to go to such an event to obtain the information, with a further $35 \%$ feeling that it was really worth the effort. In total $92 \%$ of respondents gave a rating of 4 or above. This would seem to once again reinforce the fact that they did not feel like they were wasting their time and that it was worth the effort to attend. 


\subsection{More inclined or interested in starting your own business after attending the event.}

Respondents were asked, on a scale of 1 to 5 , where 1 is "Not at all" and 5 is "Definitely" to rate how they felt as to whether they were more interested in starting their own business after attending the event. Results are shown in figure 8.

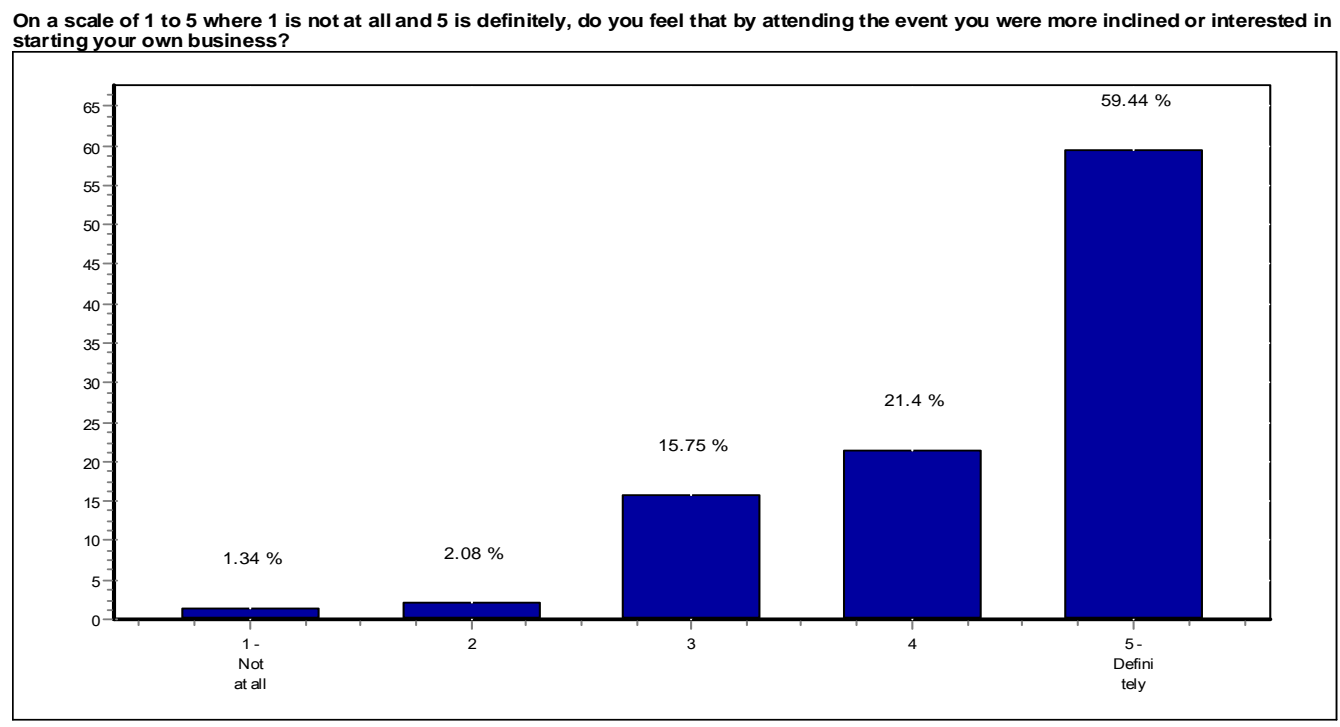

Figure 8: More inclined or interested in starting your own business

$59 \%$ of respondents gave a rating of 5 indicating that they were definitely more inclined or interested in starting their own business after attending the event, while $21 \%$ of respondents gave a rating of 4 . In total more than $80 \%$ were positive to start a business which means that the events day offer value to them.

\section{Conclusions}

The following main conclusions can be made from the responses received:

- Respondents are generally inclined to attend only one event in order to obtain information on starting their own business. A total of $82 \%$ of respondents attended the event for the first time, while those attending for a second time were only $13 \%$.

- The majority of respondents (32\%) became aware of the event via family and friends, followed by the institution itself $(26 \%)$, and newspapers $(25 \%)$.

- In total $55 \%$ of respondents were of the opinion that the event was marketed successfully, but a significant number of respondents $(34 \%)$ were neutral and $11 \%$ felt it was not well marketed, indicating a need for improvement.

- The majority of respondents (52\%) attend these events to obtain information while $47 \%$ have the attention to start their own business. This is indicative of the type of person attending these types of events and a clear indication that the correct type of people are reached with these events.

- The general feeling was that the events attended met the attendees' needs as $72 \%$ were satisfied with what the event offered.

- The main information needs of attendees were information on how to start a business (52\%), how to apply for finance $(36 \%)$, how to do market research $(29 \%)$, and how to promote the business and its products $(26 \%)$.

\section{Recommendations}

Based on the feedback received from the attendees the following recommendations can be made. 
- There was a lot of knowledge gained and hence the events were very informative and seen to add value to the attendees. This implies that these types of events must continue and hosted more often.

- The media channels that have been used to market the events should be expanded on. At present family, friends, and the institution itself, are the main marketing media. More can be done to market these events and it is suggested that social and digital media be used more extensively - as this is the way forward.

- The themes for these types of events must be structured around the identified needs of attendees. The steps involved in starting an own business for example, should be a main theme of such an event, covering all the steps and processes involved in starting an own business. This can even be made sector specific to make it more practical and attractive to entrepreneurs to attend. It is assumed that events focusing on the specific needs and demands of a specific sector or industry instead of generic will attract more interest from entrepreneurs.

- As the secondary research has shown the regulatory compliances of small businesses have proven to be cumbersome and difficult. Events should make provision for these types of challenges and give dedicated attention to skill entrepreneurs in these tasks.

- More emphasis should be placed on specific activities to assist entrepreneurs. These include how to apply for finance, how to access markets, how to conduct market research, and the marketing of the business and products. It is assumed that by focusing on specific topics the interest and attendance of these events will increase and add more value to entrepreneurs.

\section{Limitations of the study and areas for future research}

Given the relevance and importance of research into SME's it is not possible to address all relevant issues pertaining to these businesses. This study focused on specific issues and there are many issues that can and should be further investigated and researched. The researcher has identified the following areas which are limiting to the study on the one hand and on the other hand provide areas for future research.

- The study of small and micro business as a case study by universities offering work integrated learning may provide opportunities for future research and the development of curriculum to incorporate these businesses

- The focus of the study was on more urban based businesses and in so far as this is a limitation to the study it also offers the opportunity for future research in rural areas and to compare the findings of rural vs urban needs

- The focus of the study was to obtain specific information regarding events, and it may be interesting in future to have a distinction between female and male entrepreneurs and their views on these issues.

- The value and use of technology was not included in this study but it may be interesting to conduct such research in future to establish to what extend entrepreneurs rely on this technology and how they apply it.

- The study covered the educational level of respondents but no distinction was made between the literacy levels of respondents. This may be a worthwhile exercise in future to establish the different perspectives of respondents regarding literacy levels.

10. References

Acts Online. 2013. Companies Act, 1973 (Act No. 61 of 1973). [Online] Available from: http:/ / www.acts.co.za/companies-act-1973/index.html. [Accessed: 2016-02-19]. 
Agwa-Ejon, J.\& Mbohwa, C. 2015. Financial challenges faced by SMMES in Gauteng South Africa. International association for management of technology. IAMOT 2015 conference proceedings. P520534.

Bank Seta. Nd. Small and Micro-enterprises (SMEs). [Online] Available from:

http://www.bankseta.org.za/downloads/Small_and_Micro_Enterprises_Brochure.pdf.

[Downloaded: 2016-02-02].

Bureau of Economic research Report. The small, medium and Micro Enterprise sector of SA. Research note 2016: No 1. January 2016. Commissioned Research Project.

Business events: Essential tips for SMEs. Not dated. Business events: Essential tips for SMEs. [Online] Available from:

www.gevme.com/blog/business-events-essential-tips-for-smes/. [Accessed:2016-11-09].

Business Partners Limited. 2013. SMEs: be aware of necessary legal compliance needs to avoid costly lawsuits. [Online] Available from:

http:/ / www.businesspartners.co.za/media-room/posts/smes-aware-necessary-legal-complianceneeds-avoid-costly-lawsuits-1479/. [Accessed: 2016-02-19].

Department of Small Business Development. 2015. Minister Lindiwe Zulu: Small Business Development Dept. Budget Vote 2015/16. [Online] Available from: http://www.gov.za/speeches/ministerlindiwe-zulu-small-business-development-dept-budget-vote-201516-20-may-2015-0000

[Accessed: 2016-01-02].

Entrepreneur' toolkit. 2009. Small, micro and medium enterprises in South Africa. [Online] Available from:

http://www.entrepreneurstoolkit.org/index.php?title= small,_micro_and_medium_enterprises_in_South_Africa. [Accessed: 2016-02-02].

Habberton, G. \& Notcutt, K. 2013. Unlocking the growth of SMEs and social businesses in South Africa. [Online] Available from: http://impacttrust.org.za/blog/unlocking-sme-and-socialbusiness-growth-in-south-africa/. [Accessed: 2016-02-02].

SMME: Your connection to success. (/www.sme.org/events/ Accessed 9 November 2016)

Industrial Development Corporation. 2014. About IDC. [Online] Available from:

http:/ / www.idc.co.za/about-the-idc.html. [Accessed: 2016-02-09].

Infrastructure Dialogues. 2015. What is the role of infrastructure in government's strategy to revitalise township economies. [Online] Available from:

http://www.infrastructuredialogue.co.za/dialogues/township-economies/ [Accessed: 2016-01-02].

IOL. 2014. Importance of SMMEs is big business for country. [Online] Available from:

http://mini.iol.co.za/business/opinion/importance-of-smmes-is-big-business-for-country-1768670. [Accessed: 2016-01-31].

Katua, N.T. 2014. The role of SMEs in employment creation and economic growth in selected countries. International Journal of Education and research, Vol.2, No. 12.

Marnewick, C. 2014. Information and communications technology adoption amongst township micro and small business: The case of Soweto. [Online] Available from:

http://www.sajim.co.za/index.php/SAJIM/article/view/618/769. [Accessed: 2016-01-29].

Morongwa Makakane. 2014. Do SMMEs play a role in the South African Economy? [Online] Available from:

http:/ / morongwamakakane.co.za/smmes-play-role-south-african-economy/. [Accessed: 2016-0202].

Ntingi, A. 2014. SMEs hold key to unlocking SA's growth shackles. [Online] Available from:

http:/ / www.getbiz.co.za/index.php/biz-news/business-and-economy/24-smes-hold-key-tounlocking-sa-s-growth-shackles. [Accessed: 2016-01-31]. 
Organisation for Economic Co-operation and Development (OECD). 2005. Glossary of statistical terms.

[Online] Available from: https://stats.oecd.org/glossary/detail.asp?ID=3123. [Accessed: 201602-02].

Sanews.gov.za. 2014. More needs to be done for SMMEs. Thabethe. [Online] Available from:

http:/ / www.sanews.gov.za/south-africa/more-needs-be-done-smmes-thabethe. [Accessed: 2016-0131].

Seda. Nd. Who are we? [Online] Available from:

http://www.seda.org.za/AboutSEDA/Pages/WhoweAre.aspx. [Accessed: 2016-02-09].

Small business Academy research division. 2014. Khayelitsha small business project - Needs and challenges of small businesses in Khayelitsha.

SouthAfrica.info. No date. Boosting small businesses. [Online] Available from:

http://www.southafrica.info/business/trends/newbusiness/smallbusiness.htm\#.VsWx7f197IU

[Accessed 17 February 2016].

Staff writer. 2013. What SA's SME landscape looks like. [Online] Available from:

http:// businesstech.co.za/news/banking/40721/what-sas-sme-landscape-looks-like/. [Accessed: 2016-02-02].

The Banking association South Africa. 2016. SME enterprise. [Online] Available from:

http://www.banking.org.za/what-we-do/sme/sme-enterprise. [Accessed: 2016-02-02].

The department of Small business development.2015. Shared Economic Infrastructure Facility (SEIF).

[Online] Available from: http://www.dsbd.gov.za/about-dsbd.html. [Accessed: 2016-02-09].

The department of trade and industry. Nd. Institutional support for small medium micro- enterprise development.[Online] Available from:

http://www.dti.gov.za/sme_development/inst_support.jsp. [Accessed: 2016-02-09].

The department of trade and industry.Nd.The national small business development act 1996. [Online] Available from: https://www.thedti.gov.za/sme_development/docs/act.pdf. [Downloaded: 2016-02-04].

The world bank. 2016. The economics of South African Townships. [Online] Available from: http://www.worldbank.org/en/country/southafrica/publication/the-economics-of-southafrican-townships-special-focus-on-diepsloot. [Accessed: 2016-02-09].

University of Johannesburg. 2015. Township economies: job creation and competitiveness - Dr ThamiMazwai. [Online] Available from: http://www.docfoc.com/township-economies-jobcreation-and-competitiveness-dr-thami-mazwai [Accessed: 2016-02-18].

University of Stellenbosch Business School. 2014. Needs and Challenges of Small Businesses in Khayelitsha [Online] Available from: http://www.usb.ac.za/Common/pdfs/sba facts/NeedsandChallenges_3.pdf [Accessed: 2016-02-18].

WebFinancial. 2011. Importance of SME sector - or why ARC exists. [Online] Available from: http:/ / www.itweb.co.za/index.php?option=com_content\&view $=$ article\&id=45967. [Accessed: 2016-02-02].

Webster, C. \& Harris, M. 2016.SMEs and the law-do you comply? [Online] Available from: http://www.itwebinformatica.co.za/index.php?option=com_content\&view=article\&id=3970;s mes-and-the-law-do-you-comply\&catid=82:bytesize-2011\&Itemid=131. [Accessed: 2016-02-19]. 